\title{
Role of Transformational Leadership in Organizational Change: Mediating Role of Trust
}

\author{
Muhammad Hussain Uddin \\ Foundation University Institute of Engineering \& Management Sciences, New Lalazar, Rawalpindi Cantt. \\ Pakistan.
}

\begin{abstract}
To study the role of transformational leadership in organizational change and considering the mediating effect of trust the researcher conducted the study. To examine the relationship the author collected the data via questionnaires from the banking sector of Pakistan. The results are calculated by regression analysis and there is significant relationship between the transformational leadership with organizational change and trust is playing the mediating role. In the end the implications and the limitations of the research are discussed.
\end{abstract}

Keywords: Transformational leadership, Organizational change, trust, banking sector.

\section{Introduction}

The positive attitude of the leader is always comprises the accepted positive approach and the passion of skills, the energy to motivate the employees and the confidence to inspire the followers. They have the ability to develop trust, well being and commitment in relationship with the employees. The positive leadership is considered as transformational leadership (TL). Bass (1985) define the positive leadership in terms of employer's motivation and having elevating effect on followers and called such leadership as transformational leadership. The supervision always grabs the importance because it has foremost influence on employee's work either positively and negatively, more over also impact on demands, control and on social support (Harris \& Kacmar, 2006)

As studying the new millennium models the transformational leadership is considered outstanding because it incorporates visionary leadership and charismatic look and brings magnificent changes in the business and political environment (Gilbreath \& Benson, 2004). Such changes encompass the technological changes and workforce with more diversity and enhanced competition which brings more demands for the leaders (House, 1995). According to Kotter, (1995) the change management processes which necessitates the usage of innovative and different system and approaches that will makes the transformational leadership more important.

The theory of transformational leadership elucidate the leadership role and importance and Butler, Cantrell, and Flick (1999) explains the infant ideas of transformational leadership and then its ultimate effect on the political and the other writer Bass linked the role of transformational leadership within the organization and its performance as well as with the employees trust.

There is no conclusive research which studies the correlation between the transformational leadership with the organizational change (Almaraz, 1994). The research conducted in the current era trying to link the theoretical and contextual concepts of transformational leadership to give the perfect implication (Pawar and Eastman, 1997). The trust between the employee and the leader is act as a bridge which is stronger if the employee trust the leader and as a result the organization will move in the right direction.

This study aims to analyze the role of transformational leadership in organizational change with mediating effect of trust. The results of the paper will help to understand the role of leadership in the development of organization. Moreover, this paper analyzes the literature on transformational leadership and change and about the trust variable through which studied the competence essential to ratify alters productively.

\subsection{Objectives of Study}

The aim of the study is:

- To analyze the role of transformational leadership in the organizational change.

- To investigation the mediating role of trust in the relative of transformational leadership and organizational change.

\section{Literature Review}

There are four types of leadership behavior studied by Bass (1998) who concluded that transformational leader inspires the followers as behave in charismatic ways so they are always idealized. They have inspirational motivation and inspire to achieve higher goal then their followers actually think about them to 
acquire. They confront the employees to accept the challenges and initiate them to seek more than their thoughts hence have the impact of intellectual stimulations (Alban-Metcalfe \& Alimo- Metcalfe, 2000). There are many components of TL and fin Transformational leadership is a positive attitude (Carless, Wearing, \& Mann, 2000). The TL shows the concerns for the employees as well and behavior that reflect the understanding of employee's feelings and needs. This attitude leads towards the favorable responses and then ultimately causes the job satisfaction (Butler, Cantrell, \& Flick, 1999). There are many advantages of transformational leadership in the organization as it increase the task clarity and eliminate the ambiguity as provides the a frame of reference for describing anticipated performance, which decreased the perceived work stress and also enhanced the work performance (Turner et al., 2002).

There are different phases of change as management encourages long periods of small incremental changes. Such changes are cyclical in nature while they types of the organizational changes are vary which in the long run alters the organization structure and frame Tushman and Romanelli's (1985). The profound structure remains and that restricts the changes in the different time and phases of balance. Gersick (1991) introduced the Mata context which he explained as "design of the playing field and rules of the game" and called the organization adoptable of such changes. This idea was also supported by (Miller and Friesen, 1980). Nadler and Tushman (1989) discuss the role of leadership and its impact on the employees and that the follower is under the influence of leader which causes him to respond in the best possible manner to fulfill the leader requirement as concluded by Gersick (1994). Organizations respond to the employee's behavior and to the environment. (Staw, 1981). The leaders motivate the employees they achieve the required outcomes.

Dirks and Ferrin (2002) who studied the trust on leadership concluded the results as by discussing the two types of trust on the leader. These two prospective are as the one is base on relationship and the other is based on character. Mayer, Davis, and Schoorman (1995) were considered the most authenticated organizational research (Schoorman, Mayer, \& Davis, 2007).

The trust is considered as the willingness of the one party to do the other party work with the acceptance of responsibility and in the positive manner. The trust is built in this case. The organizational change is the environment is the organization which accepts the challenges and changes. In such environment they easily understand the adoption of innovative policies and happily accept the challenges and accomplish them easily (Gilbreath \& Benson, 2004).

When talking about the relationship base trust prospective the social exchange got the maximum attention in which the relationship got the status of mutual obligation not only taken in the economical advantage sharing(Podsakoff et al; 1996). This trust with the leadership also understand in the same way and the role of leader and his care for the follower is his obligation and in return he won the trust of the followers and in the organization trust of the employees(Dirks \& Ferrin, 2002). The effective leadership in the result brings the trust and this is the fruit of transformational leadership (e.g. Jung \& Avolio, 2000). Following are the hypothesis testify:

H1: There is a positive and significant relationship between the transformational leadership and the trust on leader.

$\mathrm{H} 2$ : There is a positive and significant relationship between the trust on leader and the organizational change.

H3: There is significant relationship between the transformational leadership and the organizational change.

H4: Trust has significant mediating role between the transformational leadership and the organizational change.

Theoretical Framework

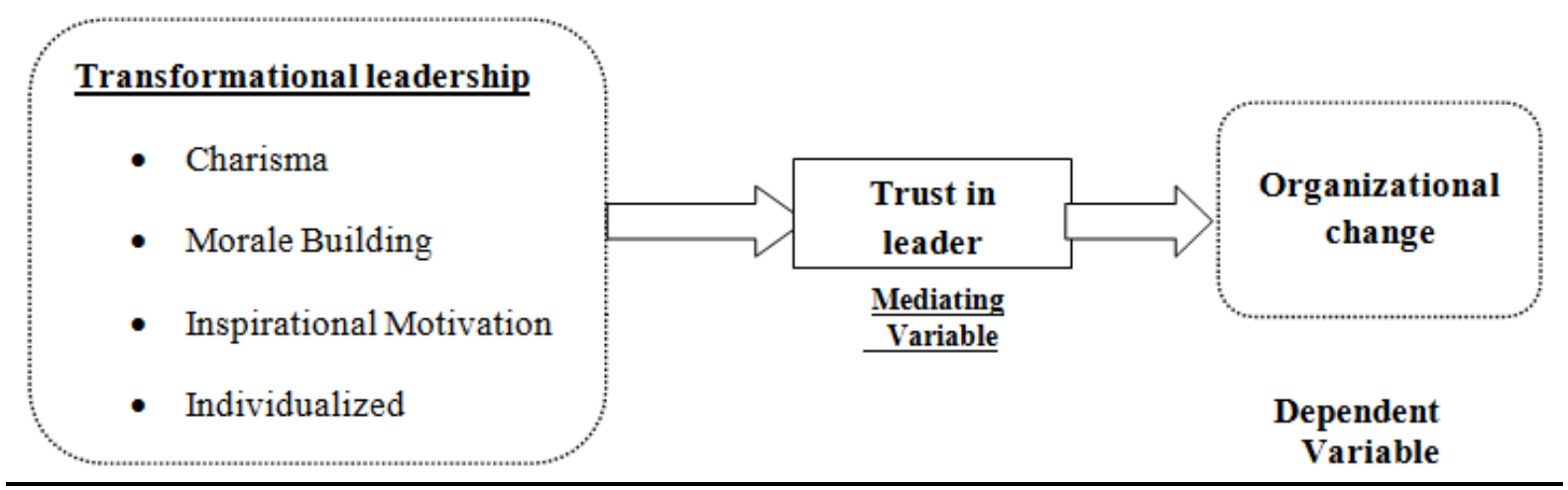

Independent

Variable 


\section{Data Collection}

\section{Methodology}

The data required for using questionnaire survey method. Questionnaire is adopted from three different researched conducted on the stated variables. The responses are analyzed by the regression analysis. Transformational Leadership is measured by using the Li and Shi's (2005) 26-item scale; four dimensions were measured, including morale building, charisma, inspirational motivation, and individual consideration. Trust on leader is measured by using the tool develops by Dirks and Ferrin's (2002). The tool used to measure organizational change is adapted from Ford and Ford, (1994). The trust on leader is the mediating variable. To study its mediating effect on the relationship between TL and OC.

\subsection{Sample Size}

The research was conducted in the Metropolitan cities of Islamabad and Rawalpindi. The reason of selecting the banking sector is as they are providing the services and there are monthly monetary targets of the banks which one should meet, so the role of leadership or manager is obvious in this sector. The top seven scheduled banks on the basis of capital share in the market is the sample of the study including, Faysal Bank limited, Muslim commercial bank, National bank of Pakistan, standard chartered bank, Bank Alfalah , Habib bank and Punjab bank.The researcher is also visiting different branches of these bank's for collecting the data. A convenience sample was used as to get the information from the required respondents. The respondents are the employees of the banks who are in managerial level. Similarly this will be the unique study in Pakistan scenario. The ratio of both genders as there are $32 \%$ females respondents while the remaining $68 \%$ were males. The Total 350 questionnaires were distributed out of which 332 were returned and 248 were completely answered. So in total respond rate was $90 \%$.

\section{Results/Analysis}

The mediated multiple regression models were used to analyze the relationship and estimate the proposed hypothesis. The results predicted that there is a positive and significant relationship between all the variables used in the study. The linear relationship between the transformational leadership and trust in leader is significant and positive as $\mathrm{t}=25.331$ while the value of $\mathrm{P}=0.000$, and the $\mathrm{R}^{2}=0.761$. Hence, $\mathrm{H} 1$ accepted as shown by the results. The trust is also significantly related with the organizational change having the $t=10.261$, $\mathrm{P}=0.000, \mathrm{R}^{2}=0.355$ so $\mathrm{H} 2$ also accepted. To check the third hypothesis the regression was applied between the Transformational Leadership and Organizational Change and the results are as the $\mathrm{t}=8.698, \mathrm{P}=0.000$, and $\mathrm{R}^{2}=.285$.

The trust on leadership is the mediating variable so to confirm the mediating role of trust on leadership the researcher applied the mediation and regression. The mediation test was carried out between transformational leadership facets and organizational change and the results are as the $\mathrm{t}=4.587, \mathrm{P}=0.000$, and $\mathrm{R}^{2}=.356$ therefore, $\mathrm{H} 4$ also accepted. This is statistically analyzed results prove that transformational leadership is related with the organizational change with the mediating effect of trust on leader.

\section{Regression Analysis}

Table No: 1

\begin{tabular}{|c|c|c|c|c|c|}
\hline & Model & $\mathbf{R}$ & $\square$ & $\mathbf{T}$ & Sig. \\
\hline 1 & TL & 0.761 & 0.873 & 25.331 & 0.000 \\
\hline 2 & OC & 0.355 & 0.596 & 10.261 & 0.000 \\
\hline 3 & OC & 0.285 & 0.534 & 8.698 & 0.000 \\
\hline
\end{tabular}

1:a.Predictors: (Constant), TL

1:b.Dependent Variable: T

2:a. Predictors: (Constant), T

2:b. Dependent Variable: OC

3:a. Predictors: (Constant), TL

3:b. Dependent Variable: OC

The above table results show that trust on leader with the organizational change which has the $\mathrm{R}^{2}$ of 0.355 and the significance level of .000 which is < than 0.05 . So when there is trust on leader then the organizational change will commence in the organization. Changes will be accepted and adopted due to trust on leadership. The transformational leadership is also having a significant relationship with the organizational change as all the facets have the p value less than 0.05 (Santos, 2003). 
The mediation conditions are fulfilled as there is significant relationship between the transformational leadership and trust on leader and organizational change (Baron and Kenny, 1986). The transformational leadership is significantly related with the organizational change and also shows the mediating effect of trust on leadership.

\begin{tabular}{|c|c|c|c|c|c|c|}
\hline \multicolumn{7}{|c|}{$\begin{array}{l}\text { Mediation Analysis } \\
\text { Table No: } 2\end{array}$} \\
\hline \multirow{2}{*}{\multicolumn{2}{|c|}{ Model }} & \multicolumn{2}{|c|}{ Unstandardized Coefficients } & $\begin{array}{l}\text { Standardized } \\
\text { Coefficients }\end{array}$ & \multirow[b]{2}{*}{$\mathrm{t}$} & \multirow[b]{2}{*}{ Sig. } \\
\hline & & $\mathrm{B}$ & Std. Error & Beta & & \\
\hline \multirow[t]{3}{*}{2} & (Constant) & 2.109 & .210 & & 10.043 & .000 \\
\hline & $\mathrm{T}$ & .390 & .085 & .558 & 4.587 & .000 \\
\hline & $\mathrm{TL}$ & .043 & .120 & .044 & .363 & .717 \\
\hline \multicolumn{7}{|c|}{ a. Dependent Variable: $\mathrm{OC}$} \\
\hline
\end{tabular}

a. Predictors: (Constant), $\mathrm{T}$

b. Predictors: (Constant), T, TL

c. Dependent Variable: OC

The $\mathrm{F}$ value change is significant and $\mathrm{t}$ values significance shows that trust is mediating the relationship between the transformation leadership and the organizational change.

\section{Conclusion:}

The results of the Transformational leadership and trust on leader proved to be significant and positively related. These results are also supported by the literature (Gersick, 1994). The trust on leader makes the employees to perform far better than they perform without having trust on the leader. This trust leads them to make the strong relationship with the employee and the leader (Dirks and Ferrin, 2002). The main reason behind it is the transformational leadership makes the employees to work in the friendly environment, the task are designed very clearly and the targets are defined. This helps the employees to work effectively and accept the challenges. The innovative policies are welcome by all and therefore, the overall performance of the employees (Pillai et al., 1999). The mediation is also significant which gives new directions to the organizations as if the employees trust on the leader so they will accept the innovative schemes and give far better performance. In the today's competitive organizational structures it is important to give best always so the role of leader is very peculiar resulting in the organizational change.

\section{Limitation And Future Directions}

The sample of the study selected in this research was contained only on metropolitan cities of Islamabad and Rawalpindi which is showing the results of relatively small sample. The same research can be performed by applying different models and by increasing the sample size. The industry of the study could be vast so to enhance the authenticity of results.

\section{References}

[1] Alban-Metcalfe, R.J., \& Alimo-Metcalfe, B. (2000). The transformational leadership questionnaire (TLQ-LGV): A convergent and discriminant validation study. Leadership \& Organization Development Journal, 21(6), 280-296.

[2] Almaraz, J. (1994), “Quality management and the process of change", Journal of Organizational Change Management, Vol. 7 No. 2, pp. 6-14.

[3] Baron, R. M. \& Kenny,D.A. (1986). The moderator- mediator variable distinction in social psychological research: Conceptual, strategic, and statistical considerations. Journal of Personality and Social Psychology, 51: 1173-1182.

[4] Bass, B.M. (1985). Leadership and performance beyond expectations. New York: Free Press

[5] Bass, B.M. (1998). Transformational leadership: Industrial, military, and educational impact. Mahwah, NJ: Lawrence Erlbaum Associates.

[6] Butler, J.K., Cantrell, R.S., \& Flick, R.J. (1999). Transformational leadership behaviors, upward trust, and satisfaction in selfmanaged work teams. Organization Development Journal, 17(1), 13-28.

[7] Carless, S.A., Wearing, A.J., \&Mann, L. (2000). A short measure of transformationalleadership. Journal of Business and Psychology, 14(3), 389-405.

[8] Casimir, G.,Waldman, D.A., Bartram, T., \& Yang, S. (2006). Trust and the relationship between leadership and follower performance: Opening the black box in Australia and China. Journal of Leadership and Organizational Studies, 12(3), 6884.

[9] Dirks, K.T., \& Ferrin, D.L. (2002). Trust in leadership: Meta-analytic findings animplications for research and practice. Journal of Applied Psychology, 87(4), 611-628.

[10] Ford, J.D. and Ford, L.W. (1994). "Logics of identity, contradiction, and attraction inchange", Academy of Management Review, Vol. 19 No. 4, October, p. 756.

[11] Gilbreath, B., \& Benson, P.G. (2004). The contribution of supervisor behaviour to employee psychological well-being. Work \& Stress, 18(3), 255-266. 
[12] Gersick, C.J.G. (1991). "Revolutionary change theories: a multi-level exploration of the punctuated equilibrium paradigm", Academy of Management Review, Vol. 16, pp. 10-36.

[13] Gersick, C.J.G. (1994), “Pacing strategic change: the case of a new venture", Academy of Management Journal, Vol. 37 No. 1, February, p. 9.

[14] Harris, K.J., \& Kacmar, K.M. (2006). Too much of a good thing: The curvilinear effect of leader-member exchange on stress. The Journal of Social Psychology, 146(1), 65-84.

[15] House, R.J. (1995), "Leadership in the twenty-first century: a speculative inquiry", in Howard, A. (Ed.), The Changing Nature of Work, Jossey-Bass, San Francisco, CA.

[16] Jung, D.I., \& Avolio, B.J. (2000). Opening the black box: An experimental investigation of the mediating effects of trust and value congruence on transformational and transactional leadership. Journal of Organizational Behavior, 21(8), 949-964

[17] Kotter, J.P. (1995). “Leading change: why transformational efforts fail", Harvard Business Review, March/April, pp. $59-67$.

[18] Li, C., \& Shi, K. (2005). The structure and measurement of transformational leadership in China. Acta Psychologica Sinica, 37(6), 803-811 (in Chinese).

[19] Mayer, R.C., Davis, J.H., \& Schoorman, F.D. (1995). An integrative model of organizational trust. Academy of Management Review, 20(3), 709-734.

[20] Miller, D. and Friesen, P.H. (1980), “Momentum and revolution in organizational adaptation", Academy of Management Journal, Vol. 23, pp. 591-614.

[21] Nadler, D.A. and Tushman, M.L. (1989), “Leadership for organizational change", inMohrman, S., Ledford, G. Jr, Cummings, T., Lawler, E. III, and Associates (Eds),Large- $\quad$ scale Organizational Change, Jossey-Bass, San Francisco, CA, pp. 100- 19

[22] Pawar, B.S. and Eastman, K.K. (1997), “The nature and implications of contextual influences on transformational leadership: a conceptual examination", Academy of Management Review, Vol. 22, pp. 80-109.

[23] Podsakoff, P.M., MacKenzie, S.B. and Bommer, W.H. (1996), “Transformational leader behaviors and substitutes for leadership as determinants of employee satisfaction, commitment, trust, and organizational citizenship behaviors",Journal of Management, Vol. 22, pp. 259-98.

[24] Santos, J. (2003), E-service quality: a model of virtual service quality dimensions, Managing Service Quality, $13(3)$, pp.233 - 246.

[25] Schoorman, F.D., Mayer, R.C., \& Davis, J.H. (2007). An integrative model of organizational trust: Past, present, and future. Academy ofManagement Review, 32(2), 344-354.

[26] Staw, B. (1981), “The escalation of commitment to a course of action", Academy of Management Review, Vol. 6, pp. 577-87.

[27] Turner, N., Barling, J., \& Zacharatos, A. (2002). Positive psychology at work. In C.R.

[28] Snyder \& S.J. Lopez (Eds.), Handbook of positive psychology (pp. 715-728). New York: Oxford University Press.

[29] Tushman, M.L. and Romanelli, E. (1985), “Organizational evolution: a metamorphosis model of convergence and reorientation", in Cummings, L.L. and Staw, B.M. (Eds), Research in Organizational Behavior, Vol. 7, JAI Press, Greenwich, CT, pp. 171-222.

\section{Originality Report}

\begin{tabular}{|l|l|l|l|}
\hline Similarity Index & Internet Sources & Publications & Student Papers \\
\hline $\mathbf{5 \%}$ & $\mathbf{2 \%}$ & $\mathbf{2 \%}$ & $\mathbf{4 \%}$ \\
\hline
\end{tabular}

